\title{
Public Debt Dynamics in the Western Balkans: Do Social Expenditures and Economic Growth Matter?
}

\author{
MILENA RADONJIĆ* \\ JOVAN ĐURAŠKOVIĆ \\ MILIVOJE RADOVIĆ \\ JULIJA CEROVIĆ SMOLOVIĆ \\ The Faculty of Economics \\ University of Montenegro \\ Podgorica, Montenegro
}

\author{
Original scientific paper \\ UDK: 364.277(497.1+497.16+497.6+497.7) \\ doi: $10.3935 /$ rsp.v27i1.1676 \\ Received: September 2019
}

The aim of this paper is to examine the determinants of public debt in the Western Balkan countries, with an emphasis on the effects of economic growth and social expenditures. The study covers the period 2006-2017, and we implement the dynamic panel GMM estimation, using both first-difference and system GMM.The results suggest that incremental growth change significantly reduces debt, while social expenditures push the debt-to-GDP ratio up. Also, there is a negative relation between inflation and debt, while interest payments on previous borrowing increase public debt additionally. Finally, unemployment is not statistically significant in this setting. The main policy implication is that policy makers in these countries should favor a growth-oriented policy toolbox and efficiency-oriented social reforms, in order to keep the public debt sustainable in the long run.

Key words: debt and growth, social expenditure, the Western Balkans.

Subject classification codes: E62, H53, H55, H61, H63

\section{INTRODUCTION}

The dramatic increase of the public debt worldwide has challenged the sustainability of the public finances in many countries. ${ }^{1}$ The public debt crisis was primarily a typical issue for the developing countries in the past, but the global crisis spillover effects have shown that many developed countries, such as the USA and many Eurozone countries, are also vulnerable to extensive government borrowings. Therefore, the economic policy makers in many countries, regardless of their development stage, are faced with the main challenge to tailor an appropriate economic policy toolkit to control public debt fluctuations and keep it sustainable in the long-run, having in mind the projected GDP growth rates.

\footnotetext{
* Milena Radonjić, The Faculty of Economics, University of Montenegro / Ekonomski fakultet, Univerzitet Crne Gore, Street of Jovan Tomasevic no. 37 / Ul. Jovana Tomaševića br. 37, 81000 Podgorica, Montenegro / Crna Gora, milena.ra@ucg.ac.me

${ }^{1}$ Authors would like to express their sincere gratitude to anonymous referees for their helpful comments and suggestions on earlier versions of this paper.
} 
Numerous studies have tried to identify the macroeconomic determinants of public debt (Swamy, 2015; Bittencourt, 2015; Globan \& Matosec, 2015; Pirtea, Nicolescu \& Mota, 2013; Budina \& Fies, 2005, and others) in order to determine the most effective policy measures that do not endanger growth. Most of comparable studies show that economic growth is crucial, and more often a single important contributing factor in public debt reduction. In addition, fiscal consolidation also proved to be an important determinant of public debt, and many EU countries were focused on fiscal consolidation as a central measure of the crisis management during the debt crisis. At the same time, it is noticeable that fiscal policy has regained a key role in achieving macroeconomic stability after a long period of the superior role of monetary policy.

The Western Balkans ${ }^{2}$ has undergone numerous economic and political structural changes in recent decades, but they have also experienced an intense public debt growth, especially during the global economic crisis. The Western Balkan countries, being highly vulnerable to the external shocks, were affected directly or indirectly by the global economic crisis, due to the spillover effects. Consequently, they experienced low, and in some cases negative economic growth rates, as well as an enormous increase in the unemployment rate. The crisis revealed a number of fiscal vulnerabilities of these countries, as well as a cyclical nature of tax revenues over the years preceding the crisis. It caused the income level to be reduced, while the public sector salaries and pensions, which account for a large proportion of government expenditure in the region (more than
$25 \%$ on average), remained high. Thus, the governments in the region intensively used their fiscal resources to manage the crisis, thus endangering their fiscal reserves and causing public debt to increase exponentially in all six countries in the region. At the end of the crisis, many countries did not manage to re-establish their pre-crisis economic growth rates, which in turn jeopardized both public debt sustainability and macroeconomic stability. Accordingly, all the governments focused on fiscal consolidation in the post-crisis years, aiming at bringing public debt back to a sustainable level.

Due to the crisis effects, many countries have introduced fiscal rules (for example, Montenegro, Albania and Serbia), while consolidation was implemented both in terms of government revenues and expenditures. For example, Albania reformed its tax system to boost tax revenues, since the proportion of government expenditure in the GDP was not particularly large. On the other hand, the Serbian government implemented fiscal consolidation to control expenditures, since the state budget was burdened by inflated public sector expenditures and pensions. Fiscal consolidation reduced the deficit in the short-run, but further fiscal consolidation is necessary to stabilize the debt dynamics in all Western Balkan countries. On the other hand, sluggish economic growth hampers the debt dynamics of the region, since it affects the fiscal positions of these countries the most. According to the World Bank, the Western Balkans has made significant progress since the transition era of the 1990s, but the structural reforms are still an ongoing process. The major problem facing the region is a low productivity

\footnotetext{
${ }^{2}$ Following the EU definition, this term refers to Balkan area countries (Albania, Bosnia \& Herzegovina, Kosovo, Macedonia, Montenegro and Serbia) that are not members of the European Union, but each aims to be part of the future enlargement. This designation is without prejudice to positions on status, and in line with UNSCR 1244 and the ICJ Opinion on the Kosovo Declaration of Independence.
} 
that reflects years of low investment, weak institutions and a difficult business environment (World Bank, 2017).

Having in mind the overall economic and political context in this region, there are several important problems that should be addressed in the context of an appropriate economic policy toolbox to ensure a sustainable path of public debt in the coming years. The aim of this paper is to examine the potential determinants of public debt dynamics, particularly what are the debt effects of economic growth and social policy in the Western Balkans. Specifically, we hypothesize that the relation between growth and public debt is negative and significant, while the relation between social policy, proxied by total social expenditures, is positive and significant.

To be more specific with respect to social expenditures, it is worth emphasizing the nature of these fiscal costs. Namely, social outlays are at the same time benefits offered by governments to specific social groups that do not meet predefined social standards. According to IMF (2014), "social benefits are current transfers receivable by households intended to provide for the needs that arise from social risks - for example, sickness, unemployment, retirement, housing, education, or family circumstances. These benefits are payable in cash or in kind to protect the entire population or specific segments of it against certain social risks. Examples of social benefits are the provision of medical services, unemployment compensation, and social security pensions." Thus, the main research problem here is to determine if public debt is driven by the growth rate and social expenditures, and if so, what the policy-related recipe to keep the debt position sustainable would be in the long-run.

The major contributing elements of the study, comparing to the existing literature, are related to both quantitative and qualita- tive research outcomes. Namely, the study employs two comparable dynamic panel estimators, the Arellano and Bond (1991) difference GMM and Blundell and Bond (1998) system GMM with additional moments' restrictions. In addition, to our best knowledge a similar study that deals with the same sample has not been conducted yet, making a particular contribution to the existing literature body. Finally, the practical implications of the study are not questionable, since the results can serve as a useful guide for policy makers to create a sound and effective fiscal measure, aiming to regain a balanced fiscal position and macroeconomic stability.

The study is structured as follows. After the introductory notes, we surveyed the most relevant empirical studies dealing with the public debt determinants worldwide, with an emphasis on their methodological approaches, main results and policy implications. The following section includes the data description, methodological framework, variable selection, and model specification. The next section presents the empirical results and discussion, where the latter compares our findings with the previous empirical evidence, followed by the conclusion.

\section{LITERATURE REVIEW}

The increasing public debt worldwide has sparked debates on the debt-related macroeconomic performances, primarily on growth dynamics. Numerous studies have shown that a high level of public debt (over 90\% as a share of the GDP) is associated with lower, and even negative growth rates, in both developed and developing countries (Akram, 2016; Mencinger, Aristovnik \& Verbič, 2014; Panizza \& Presbitero, 2013; Minea \& Parent, 2012; Reinhart \& Rogoff, 2010; Kumar \& Woo, 2010, and others). In a very extensive empirical investigation, Swamy (2015) examines the 
main macroeconomic drivers of public debt, where the study includes 252 countries and covers a 30 -year period. The results show that the real economic growth, foreign direct investment, government expenditure and inflation are negatively correlated with public debt. On the other hand, public debt is positively correlated with gross fixed capital formation, final consumption and trade openness. In a more sophisticated study, Sinha, Arora and Bansal (2011) emphasize the fact that the determinants of public debt differ across countries, having in mind their development status (high-income or middle-income economies). Their study shows that the growth rate, government expenditure, education spending, and the current account balance are the most important driving forces of public debt in both groups of countries. On the other hand, some variables such as foreign direct investment and inflation, do not affect public debt in high-income countries, but they are significant determinants of public debt in middle-income countries.

The existing literature also recognizes that the public debt determinants can exhibit cross-effects, thereby mitigating or enhancing their initial public debt effects. For example, an interest rate shock can lead to an increasing debt-to-GDP ratio and it can also adversely affect economic growth, which further deteriorates the public debt dynamics. If the government implements fiscal consolidation to prevent the debt crisis, it could have beneficial effects on the debt itself, but the effects of the initial interest rate shock could not be easily determined. For example, on a sample of 15 developed economies, Anaya and Pienkowski (2015) examine such cross-effects on a sample of 15 developed economies, showing that such an interest rate shock acts as a public debt stabilizer, while a growth-related shock intensifies debt accumulation. In addition, the public debt dynamics depends significantly on the prevailing monetary policy regime, because those countries that have a constrained monetary policy must rely on the fiscal policy to stabilize the public debt growth rates.

Some recent studies emphasize the role of inflation in determining the level of public debt, since it can have an impact on both government revenues and expenditures. For example, Aizenman and Marion (2011) show that an inflation rate of $6 \%$ leads to a $20 \%$ reduction in the debt-to-GDP ratio in the USA, over a four-year timeframe. More interestingly, Hall and Sargent (2010) conclude that inflation played a crucial role in reducing the US public debt in the period 1946-1974. Conversely, Forslund, Lima and Panizza (2011) show that inflation in the past did not play a significant role in driving the debt-to-GDP ratio of the emerging market economies. Consequently, these studies support an intuition that the impact of inflation on debt depends heavily upon the developmental stage of the countries that comprise the research sample.

Going back to our main research problem, we find that the vast majority of the empirical studies support the assumption that economic growth determines public debt critically. For example, Easterly (2011) shows that, regardless of developmental status, the economic slowdown in the post-1975 had significant implications for the fiscal stability of both developed and developing countries. Namely, modest growth rates led to a reduction in the present value of tax revenues and budget surpluses, which increased the public debt burden even further. Therefore, sluggish economic growth in many industrialized countries played a significant role in their debt crises. The same effect is visible for the middle-income countries in the 1980s and the heavily indebted poor countries (HIPCs) in the 1980s and 1990s. Similarly, Bittencourt (2015) examines the impact of 
macroeconomic factors on the public debt dynamics in nine South American countries, between 1980 and 2009. It is worth mentioning that all of these countries went through significant structural economic and political changes during the observed period, implying that these structural turbulences must be taken into account when deciding about the final effects. The study identifies that only economic growth has significantly reduced the debt ratios in the region, while other possible factors, such as inflation, inequality, and constraints on the executive do not have a significant impact on the public debt dynamics. In addition, Cherif and Hasanov (2012) found that the debt in the USA is manly growth-driven, while the austerity policy or fiscal consolidation proved to be ineffective. Finally, Proaño, Barbosa de Carvalho, and Barbosa-Filho (2012) are more specific, saying that austerity policy is effective in reducing public debt if the growth rate exceeds the real interest rate, even when the primary balance deteriorates.

Apart from the growth-debt empirical investigations, there are studies that identify fiscal consolidation as an important determinant of the public debt fluctuations. For example, Abbas, Akitoby, Andritzky, Berger, Komatsuzaki and Tyson (2014) explore 26 episodes of large public debt reductions in 20 developed economies, covering the period 1980-2013. The results show that these countries mainly used a proactive growth policy and well-designed consolidation to reduce public debt. In addition, inflation, the interest rates and stock-flow adjustments had a negligible impact on public debt, compared to the high growth rates of economic growth and strong-constrained primary balance. Accordingly, a well-designed set of economic and fiscal measures aimed to encourage economic growth and consolidating public finance would contribute to reducing public debt much more than the monetary policy actions targeting money supply.

There are also numerous studies that focus exclusively on fiscal consolidation as the main policy tool to control public debt, though the empirical findings are mixed because of different research samples. For example, Daniel, Callen, Terrones, Debrun and Allard (2003) examine the relationship between public debt and fiscal consolidation (approximated by the primary balance) in both developing and developed countries. The results show that the primary balance, for any level of public debt, is lower in developing than in developed countries. In addition, the effect of the primary balance on public debt reduction weakens at higher public debt levels, and completely disappears when the debt-to-GDP ratio rises above $50 \%$ in developing countries. This finding is completely in line with the results provided by Mendoza and Ostry (2007). As for the developed countries, the public debt effect of the primary balance is accelerated when the debt-to-GDP ratio exceeds $80 \%$, and it becomes three times stronger than at the lower debt levels. Furthermore, Budina and Fies (2005) point out that both primary balance and growth, together with fiscal consolidation, the interest rate, exchange rate and some one-off events (e.g. privatization or bank bailouts) significantly affect public debt in the selected market-access countries. Finally, Cafiso and Cellini (2012) provide evidence that fiscal consolidation in the selected EU countries can slow down an increasing public debt, while its effects are much greater if consolidation is based on reducing consumption rather than increasing tax rates.

The academic debate about the public debt dynamics in the EU countries in the post-crisis years are also interesting. Namely, the crisis hit the Eurozone economies, especially those from the south periphery (Portugal, Greece, Italy, and Spain), due to 
global economic cross-country relations, and the new challenges revived the debate about the strengths and weaknesses of the anti-crisis fiscal policy. Mota, Costa Fernandes and Nicolescu (2012) show that the main factor that led to the crisis in the European Union was a sharp GDP contraction, resulting in decreasing investors confidence and rising interest rates. This experience showed that debt crisis management should rather be based on fiscal consolidation than on a growth-focused policy, aiming to boost domestic demand in the case of peripheral Eurozone countries and to encourage domestic demand in more advanced EU economies such as Germany. Italy, as a particular example, has experienced a sharp decline in the GDP over the crisis years, and a policy-focused case study has shown that the economic policy that supports economic growth of over $1.8 \%$ per year can reduce the Italian debt-to-GDP ratio to $100 \%$ (Casadio, Paradiso \& Bhaskara, 2012). Having in mind that the Italian economy depends heavily upon a favorable international macroeconomic environment, favorable oil prices and a "weak" euro would also be important contribution factors of a successful debt-related economic policy. In addition, the expansionary monetary policy of the European Central Bank that would reduce the interest rates would also build momentum.

As for the public debt studies that deal with the new member states, it is a wellknown fact that these countries initially contributed to the growth in the EU, but then plummeted into a debt crisis and largescale macroeconomic instability. Many empirical studies have shown that these pressures required a quick policy response, and many new member states have been implementing strong fiscal consolidation, even after a decade of the initial crisis wave. For example, Sever, Drezgić and Blažić (2011) point out that the structure of the budgetary spending is essential for economic growth in Croatia, with a positive effect of public investments on the growth dynamics. Also, Dalić (2013) investigates the growth effects of fiscal policy in the new member states (NMS) of the EU using the panel regression framework. The author does not find the positive effect of social expenditures on growth, while the investment effects are weak and not robust to dynamic specification. Finally, highly volatile government investments harm economic growth. Finally, Globan and Matosec (2015) show that GDP growth is the most important factor of reducing the relative proportion of public debt in the new member states, although a balanced budget can also be a contributing factor, but with limited effects. Accordingly, they suggest that a successful debt management should be based on the measures that target economic growth, while irresponsible public finance management would lead to additional costs.

Furthermore, Pirte, Nicolescu and Mota (2013) obtained similar results for Romania, finding that the primary fiscal balance, economic growth, real interest rate and exchange rate are the most important driving factors of public debt. The study also shows that the effect of growth on public debt reduction was particularly intense in the post-crisis period. In another country-based empirical study, Šimović, Ćorić, and Deskar-Śkrbić (2014) investigate the possibilities of fiscal policy in Croatia, in particular, the effect of revenue and cost budget structure on the GDP dynamics. They employ the Vector Autoregressive model (VAR), aiming at proposing a version of a smart fiscal consolidation as a prerequisite for fiscal stabilization. Based on the impulse-response forecast, government purchases, social benefits and subsidies have a positive effect on GDP in the short-run, and negative in the long-run. It is also concluded that direct taxes, particularly income taxes have the long-lasting negative effects on growth. 
Finally, there is a significant literature body dealing with social policy as a contributing factor of public debt dynamics, although there are some recent attempts to combine growth and social expenditures to address potential reverse causality running from debt to social benefits. For example, Lora and Olivera (2007) explore the effects of the total public debt (external and domestic) on social expenditure worldwide and in Latin America in an unbalanced panel fashion, covering the period 19852003. Their results indicate that defaulting on debt obligations helps to increase social expenditures. Also, many of the findings are heterodox and country-specific, but they conclude that there is no better way to protect social expenditures than to avoid over indebtedness, especially in Latin America. In a more recent study, Czech and Tusins$\mathrm{ka}$ (2015) investigate the causality between high welfare spending and the growing public debt in 21 highly developed countries, covering the period 1991-2014. They found that the effects of high social benefits on debt are country-specific and mixed, with no straightforward conclusion about the direction and magnitude of this impact in particular cases.

The relationship between fiscal policy, debt, and social outlays on one hand, and economic growth on the other hand, has attracted considerable attention of the international financial institutions, mainly the World Bank and IMF. Most of these studies target international and global dimension of the problem, where empirical investigations deal with different global regions and country groups. For example, there are very interesting observations of the effects of fiscal policy on economic growth in Eastern Europe and Central Asia provided by the World Bank (2007). The study suggests that macroeconomic stability is the key contributor of the long-term growth, "while moderate levels of public spending - around one-third of GDP or less-are preferable to high levels when governance and public administration are not strong". Finally, investment and growth are constrained by an "aggressive" taxation, while social expenditures contribute to growth. Also, López, Thomas and Wang (2008) propose several measures that can be implemented to improve quality of growth in the longrun. Specifically, they conclude that restructuring government spending, tax system reforms, rational social expenditures, and more extensive public good offer enhance the quality of economic growth worldwide.

More recently, Brahmbhatt and Canuto (2012) reconsidered the role of fiscal policy and economic development in the aftermath of the global financial crisis (2007-2008). Specifically, they evaluate how fiscal positions in developing countries have evolved in the wake of the crisis. The main recipe for the countries is to build a sound fiscal position during the normal time, especially rationalizing social benefits, since it allows them to avoid radical discretionary expenditure cuts during that crisis, which can in turn harm economic growth additionally. Finally, the recent IMF (2019) policy paper prescribes a more effective social spending management that would include social spending "floors" in the IMF-supported programs. In addition, "the key channels through which social spending can become macro-critical are fiscal sustainability, spending adequacy, and spending efficiency. The strategy encourages early engagement with the authorities and envisages that staff continues developing policy advice on sustainable financing of social spending and increases the focus on the quality of such spending for improving social outcomes, drawing on the expertise of IDIs."

Another multidimensional study by Chang, Lee, Geng and Ning (2016) investigates the link between social expenditures and rising public debt in 13 OECD countries, taking into account both direct 
and reverse causalities. They found that higher social expenditures increase government debts, while the shocks from the government debts to social expenditures are conversely uncertain. Namely, higher government debt does reduce social expenditures, but it may be linked to higher social spending. In addition, Akram (2015) deals with the reverse causality, showing that high public debt is indifferent to the rich/ poor population, since the external debt is not associated with higher inequality in the selected Asian countries. Also, Alesina and Passalacqua (2015) emphasize political aspects of the public debt dynamics, concluding that the political cycles connected with the electoral periods also affect the public debt and social setting in many developed countries. Finally, Lee (2017) deals with the causality between social expenditures and public debt in 34 OECD countries, covering the period 1980-2014. The study reveals robust evidence that the rise in public debt is not attributable to social expenditure.

As we can see, most of these studies are based on static balanced or unbalanced panel estimations, taking into account either the general macroeconomic aspect or the social aspect of rising public debt, both in direct relation or assuming reverse causality. However, this study is specific to the public debt model as it uses both aspects and estimates the causalities in a dynamic panel fashion. In addition, there is no single study dealing with the Western Balkan countries, which makes this study unique to a certain point. So, the paper aims to fill the gap in the existing literature and provide some policy implications regarding future fiscal and social policy actions in these countries.

\section{DATA AND METHODOLOGY}

The data are obtained from multiple sources, such as the IMF's World Economic Outlook Database, the World Bank's World Development Indicator (WDI) database and the statistical bureaus of the analyzed countries. Our analysis is based on the annual data for six countries in the Western Balkans (Albania, Bosnia and Herzegovina, Kosovo, Macedonia, Montenegro and Serbia), covering the period 2006-2017. Specifically, the database includes the selected macroeconomic variables such as GDP growth, inflation, unemployment, debt interest payments, and social expenditures as a social policy proxy, arranged in a balanced panel fashion.

The empirical investigation has three subsequent stages, starting from the stationarity check to model specification and dynamic panel data estimation. Specifically, the model specification and selection of an efficient estimator is based on the preliminary RESET test to check the assumed linear relations. Since we are dealing with the macroeconomic variables that have well-known lagged effects and some of them have proved to be highly correlated, causing potential multicollinearity problem, we have chosen a dynamic GMM estimator. Following Hansen (1982), the generic GMM estimator assumes that a sample of T observations is drawn from the joint probability distribution: $f\left(w_{1}, w_{2}, \ldots, w_{T}, \theta_{0}\right)$, where $\theta_{0}$ is the $(q \times 1)$ vector of true parameters and $w_{t}$ contains one or more endogenous and/ or exogenous variables. The population moments condition is given as follows:

$$
\mathbb{E}[m(w t, \theta 0)]=0 \quad \text { for all } \mathrm{t},
$$

where $m(\cdot)$ is the r-dimensional vector of functions. The estimator is dealing with three cases: (a) $q>r$, meaning that the parameters in $\theta$ are not identified; (b) $q=r$, meaning that the parameters in $\theta$ are exactly identified; and (c) $q<r$, meaning that the parameters in $\theta$ are overidentified and the moments conditions have to be restricted by weighting the matrix $A t$, in order to deliver a unique $\theta$ in the estimation. The estima- 
tion is based on the empirical counterpart of $\mathbb{E}\left[m\left(w_{t}, \theta_{0}\right)\right]$ :

$$
M_{T}(\theta)=\frac{1}{T} \sum_{t=1}^{T} m\left(w_{T}, \theta_{0}\right)
$$

where $M_{T}(\theta)$ is the r-dimensional vector of sample moments. In addition, the GMM estimator of $\theta$ is based on the following specification:

$$
\hat{\theta}_{T}=\operatorname{argmin}_{\theta \in \Theta}\left\{M_{T}(\theta) A_{T}, M_{T}(\theta)\right\},
$$

where $A_{T}$ is a $r \times r$ positive semi-define, possibly random weighting matrix. To obtain an efficient estimator, we have to choose the weighting matrix that minimizes the covariance matrix of $\hat{\theta}$. Furthermore, Arellano and Bond (1991) suggest using a GMM approach based on all available conditions, starting from the first difference estimator specified as follows:

$$
\Delta y_{i t}=\gamma \Delta y_{i t-1}+\beta^{`} \Delta x_{i t}+\Delta \varepsilon_{i t}
$$

It is obvious that for $t=(1,2)$, there are no valid instruments, while for $t=T$, the valid instrument for $\Delta_{y i T-1}=\left(y_{i T-1}-y_{i T-2}\right)$ is $y_{i T-2}$, as well as the recent time-ordered dependent variable $\left(y_{i T-3}, y_{i T-4}, \ldots . y_{i T-(T-1)}\right)$. The corresponding matrix of instruments for the lagged difference consists of a diagonal combination of the time-ordered dependent variable, with off-diagonal zeros. The moment conditions are defined as $\mathbb{E}\left[m\left(W_{i}, \Delta \varepsilon_{i}\right)\right]=0$, while the corresponding GMM estimator is formulated as follows:

$$
\hat{\lambda}^{G M M}=\left(G^{`} Z S_{N} Z^{\prime} G\right)^{-1} G^{`} Z S_{N} Z^{`} \Delta y,
$$

w h e r e $\hat{\lambda}^{G M M}=\left[\hat{\gamma}^{G M M}, \hat{\beta}^{G M M}\right]$, $G=\left(\Delta y_{t-1}, \Delta X\right), Z=(W,, \Delta X)$, while $S_{N}$ is an optimal weighting matrix that maxi- mizes the covariance matrix of $\hat{\theta}$. It is an efficient estimator, but the efficiency deteriorates as $y_{i t}$ exhibits substantial persistence $(\gamma \rightarrow 1)$ and as $\sigma_{\mu}$ increases relatively to $\sigma_{\varepsilon}$. The consistency of the GMM estimator is based on the assumption that the transformed error term is not serially correlated, i.e., $\mathbb{E}\left(\Delta \varepsilon_{i t}, \Delta \varepsilon_{i t-2}\right)=0$, which we obtain by testing the residuals from the first-difference equation.

Blundell and Bond (1998) further advanced the GMM specification, proposing an estimator that includes additional moment restrictions, particularly on the distribution of initial values $\left(y_{i 0}\right)$. This set of restrictions is important when $\gamma$ is close to unity and/or when $\sigma_{\mu} / \sigma_{\varepsilon}$ becomes large. If we assume that the differenced dependent variable is orthogonal to the sample average, then the following moment conditions can be implemented:

$$
\mathbb{E}\left[\left(y_{i t}, \gamma y_{i t-1}\right)\right]=0
$$

Finally, the Blundell-Bond system GMM exploits the instrument matrix form the Arelano-Bond first-difference GMM, and adds additional diagonal entries, specifically the first-differenced dependent variable throughout the observation period.

Taking into account these methodological remarks, we first check the stationarity of the variables, and then investigate whether the relationship between a set of independent variables is linear or non-linear, using the RESET test. To be more specific, we implement the two-step procedure (Enders, 2015):

Step 1: Estimate the best-fitting linear model. Let $\left\{e_{t}\right\}$ be the residuals from the model and denote the fitted values by $\hat{y}_{t}$.

Step 2: Select a value of H (usually 3 or 4) and estimate the regression equation: 


$$
e_{t}=\delta z_{t}+\sum_{h=2}^{H} \alpha_{h} \hat{y}_{t}^{h} \quad \text { for } H \geq 2 \text {, }
$$

where $z_{t}$ is the vector that contains the variables included in the model estimated in Step 1. Finally, we have formulated the following model specification (matrix form):

$$
\Delta Y_{i t}=\gamma \Delta Y_{i t-1}+\beta \Delta X_{i t}+\Delta \varepsilon_{i t}
$$

where $\Delta Y_{i t}$ represents the first-differenced public debt across the sample, $\hat{\beta}$ is a transposed vector of the coefficients, $\Delta X_{i t}$ is the first-differenced matrix of independent variables, and $\Delta \varepsilon_{i t}$ is the first-differenced error term. To be more specific, the extended first-difference public debt model is given in the following specification:

$$
\begin{gathered}
\Delta \text { Debt }_{i t}=\gamma \Delta D e b t_{i t-1}+\beta_{1} \Delta G D P_{i t}+ \\
+\beta_{2} \Delta \text { Soc }_{i t}+\beta_{3} \Delta \operatorname{Inf}_{i t}+\beta_{3} \Delta \text { Unemp }_{i t} \\
+\beta_{3} \Delta \text { IntPay } \\
\text { it } \\
+\Delta \varepsilon_{i t}
\end{gathered}
$$

where $D e b t_{i t}$ is public debt, GDP ${ }_{i t}$ represents the GDP growth rate, $S o c_{i t}$ includes social expenditures (measured as a share of the sum of education, health and social benefits in the GDP). In addition, $\operatorname{Inf} f_{i t}$ represents the annual inflation rate, Unemp represents the annual unemployment rate, while IntPay ${ }_{i t}$ represents interest payments as a share of the GDP. Finally, the subscript it denotes country $i$ in period $t$ (the same notification for all the variables). Following Arellano (2003), we constrained the coefficients in certain lags to be zero, when projecting regressors onto the instrument set. Also, certain singular instruments are automatically dropped provided that the identification is maintained.

It is worth noting that the above specification is based on the previous similar stu- dies (Bittencort, 2015; Globan \& Matosec, 2015; Swamy, 2015; Pirtea, Nicolescu \& Mota, 2013; Sinha, Arora \& Bansal, 2011), and that there are well-known transmission channels that affect public debt. According to Bittencort (2015) and Krugman (2010), the countries with faster economic growth should experience a decreasing public debt, meaning that the growth-debt relation is expected to be negative. Social expenditures create an additional fiscal burden, but also contribute to economic development up to a certain point. Accordingly, this relationship could be positive, negative or insignificant. In addition, inflation erodes the domestic public debt and there are suggestions from the related literature that a low and stable inflation rate contributes to growth. Consequently, we might expect the relationship between inflation and debt to be negative. As for unemployment, the labor market surplus causes lower current government revenues and higher welfare spending, which increases the fiscal burden (Castells-Quintana \& Royuela, 2012: 156). Therefore, it is expected that unemployment is positively related to debt. Finally, interest expenses represent a component of budget balance, together with the primary balance. While primary balance shows the efficiency of fiscal adjustments aimed at decreasing current deficit, it is still possible to record a rise in public debt due to rising interest rates ( $\mathrm{S} \mathrm{i}$ mović, 2018: 235). Thus, the literature suggests a positive and significant associationship between interest payments and debt.

The post estimation strategy includes the Sargan-Hansen validity test of the over-identifying restrictions (J-statistics), assuming that that model parameters are identified via a priori restrictions on the coefficients. Under the null hypothesis that the over-identifying restrictions is valid, we basically test the validity of the instruments, where the J-statistics follows the chi-square distribution with $(m-k)$ degrees of freedom ( $m=$ number of instruments, $k=$ 
number of endogenous variables). In addition, we test the normality assumption of the residuals from the first differenced equation using the Jacque-Berra LR-type test, assuming that the error terms are normally distributed. We also tested the hypothesis of no serial correlation between the residuals (both at lag $\mathrm{h}$ and between lag 1 and lag h, with maximum 3 lags) using the Edgeworth expansion LR and Rao F-test. Finally, we check the cross-sectional dependence within the panel using the Breusch-Pagan LM test, Pesaran scaled the LM test and CD test. Under the null hypothesis, $u_{i t}$ is assumed to be independent and identically distributed (i.i.d.) over periods and across cross-sectional units. Under the alternative, $u_{i t}$ may be correlated across cross sections, but the assumption

\section{EMPIRICAL RESULTS AND DISCUSSION}

\section{Descriptive Analysis}

The empirical section presents a descriptive analysis of the level-based changes of the selected variables, and includes the cross-country comparisons between public debt, the GDP and social expenditures. In addition, we scrutinize the sample using a standardized set of descriptive statistical indicators (including skewness and kurtosis), coupled with the correlation matrix of the differenced series. The country-based trends for debt-to-GDP ratio, the GDP growth rate and social expenditures (as a share in the GDP) are presented in the following figures.

Graph 1

Debt-to-GDP ratio

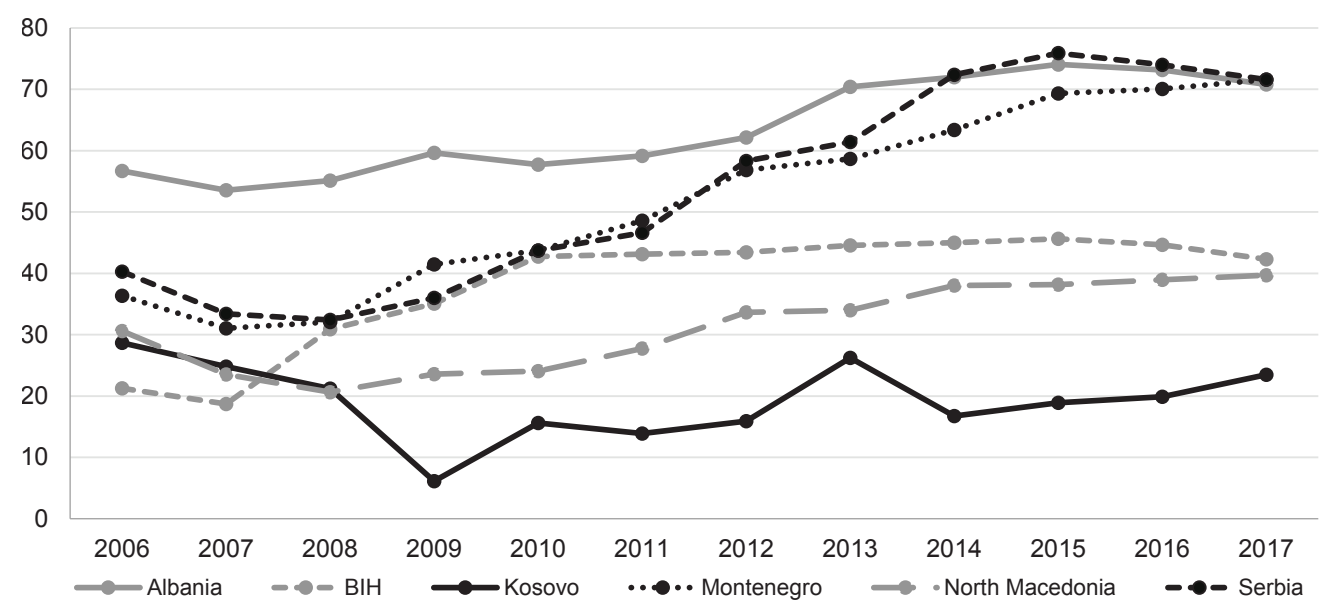

Source: IMF, World Bank, WEO, and National Statistical Offices.

of no serial correlation remains (Pesaran, 2004). Finally, we use the Arellano-Bond test for zero autocorrelation in first-differenced errors, with the null hypothesis of no autocorrelation.
Graph 1 shows the debt-to-GDP ratio dynamics in 6 Western Balkan countries. As we can see, the observed period is characterized by a huge increase in the debt-toGDP, and it is especially visible for Serbia, 
Montenegro and Bosnia and Herzegovina (BIH). Talking about the exact figures, the debt of Serbia and Montenegro increased for $35.25 \%, 31.28 \%$ and $21.04 \%$ respectively, comparing the ratios between 2017 and 2006. Also, Albania, Serbia and Montenegro have much bigger average debt-toGDP ratios $(68.71 \%, 53.83 \%$ and $51.92 \%$, respectively) during the observed period, compared to the regional average (42.98\%). At the regional level, the debt-to-GDP ratio has increased by $3.96 \%$ on average over the observed period. But this regional figure hides some extreme changes in the ratio at the country level. For example, the ratio increased rapidly in $\mathrm{BIH}$ in 2008 (65.10\%), in Kosovo in 2010 and 2013 (154.98\% and $64.70 \%$ ), in Montenegro in 2009 (29.22\%), in North Macedonia in 2012 (21.38\%), and in Serbia in 2010 and 2012 (21.39\% and $25.11 \%$ ). The biggest average growth rate of the debt-to-GDP ratio is recorded in Kosovo (11.28\%).
Graph 2 shows the GDP growth rates in the selected countries over the period 2006-2017. At first glance, it is obvious that a sudden GDP drop is partially responsible for rapid jumps in the debt-toGDP ratio. As we can see, the countries that have experienced the biggest increase in the debt ratio have at the same time experienced the biggest recessions, such as Serbia and Montenegro. If we take into account the exact figures, Montenegro, Serbia, and BIH experienced the biggest drop in GDP growth $(-5.5 \%,-2.4 \%$ and $2.3 \%$, respectively) in 2017 compared to 2006. The average growth rate over the observed period at the regional level is $2.8 \%$, with the biggest average recorded for Kosovo (3.7\%) and $2.9 \%$ (Montenegro). It is obvious that the region was hit by the spillover effects of the global financial crisis, causing a significant GDP drop, followed by decreasing government revenues and increasing public borrowing.

Graph 2

GDP growth rates

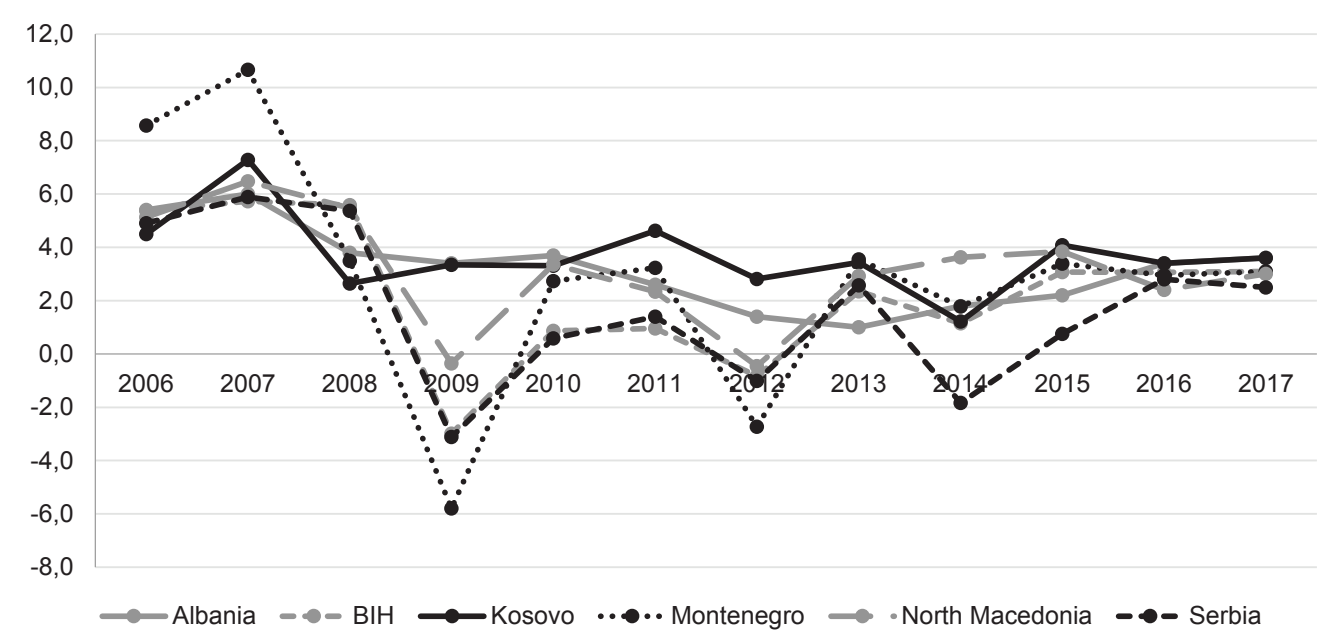

Source: IMF, World Bank, WEO, and National Statistical Offices. 
Graph 3 shows the trends in social expenditures for the selected Western Balkan countries, over the period 2006-2017. As we can see, we have almost a constant trend for all countries, meaning that they just maintained a predefined level of social costs relative to the GDP.
The level-based trends of the macroeconomic and social indicators for the whole sample are presented in Graph 4. At first glance, the indicators show a highly cyclical pattern and huge heterogeneity across the sample. Specifically, Albania, Montenegro and Serbia have experienced a huge jump

Graph 3

Social expenditures (share in GDP)

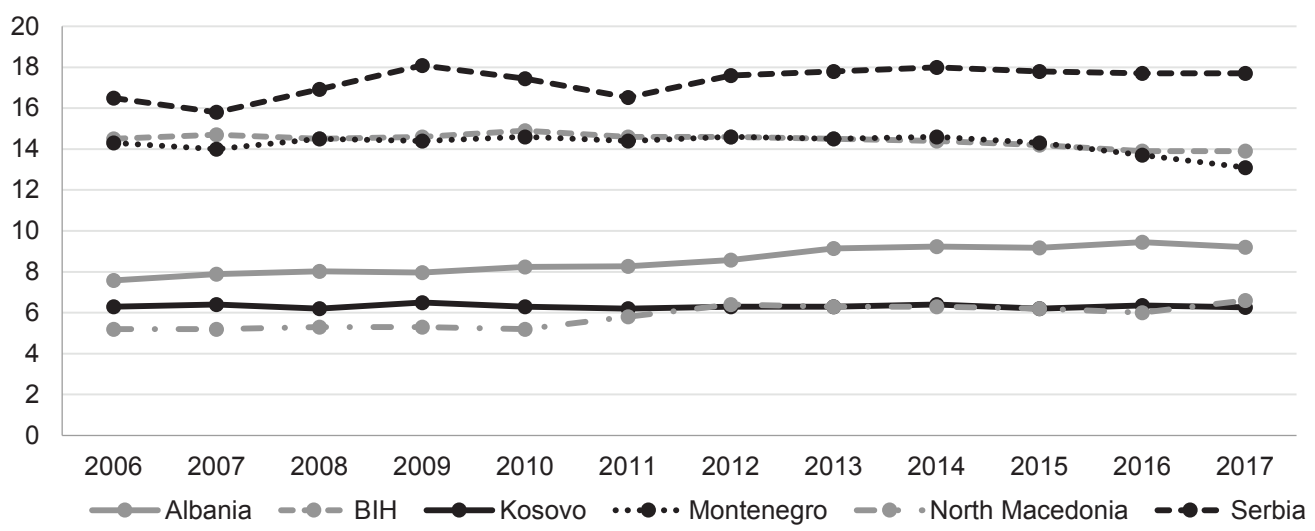

Source: IMF, World Bank, WEO, and National Statistical Offices.

Based on the social expenditure trends, these countries have tried to maintain the same level of welfare setting, having in mind harsh economic conditions caused by the crisis. It is clear that the countries decreased social benefits proportionally to the GDP decrease, meaning that the largescale fiscal decentralization was primarily based on social cuttings. The biggest average share of social costs in the GDP over the observed period is recorded in Serbia (17.3\%), BIH (14.4\%), Montenegro (14.3\%). Comparing the figures between 2017 and 2006, BIH (-0.6\%) and Montenegro (-1.2\%) decreased their social costs relative to the GDP, while North Macedonia (1.4\%) and Serbia $(1.2 \%)$ increased their social costs relative to the GDP. in debt, compared to other countries, followed by the same pattern of interest payments. The social cost trajectory reflects those country-level differences, where Serbia leads in social expenditures, followed by BIH and Montenegro. There is also a huge difference in the unemployment rate between Albania and Serbia (low unemployment) on one hand, and the rest of the sample (high unemployment), on the other hand. Finally, the inflation rate clearly shows a low inflation environment in Albania, while other countries are characterized by a high inflation environment. Overall, we are dealing with an extremely heterogeneous sample, where country-specific heterogeneity dominates the timetrend effects. 


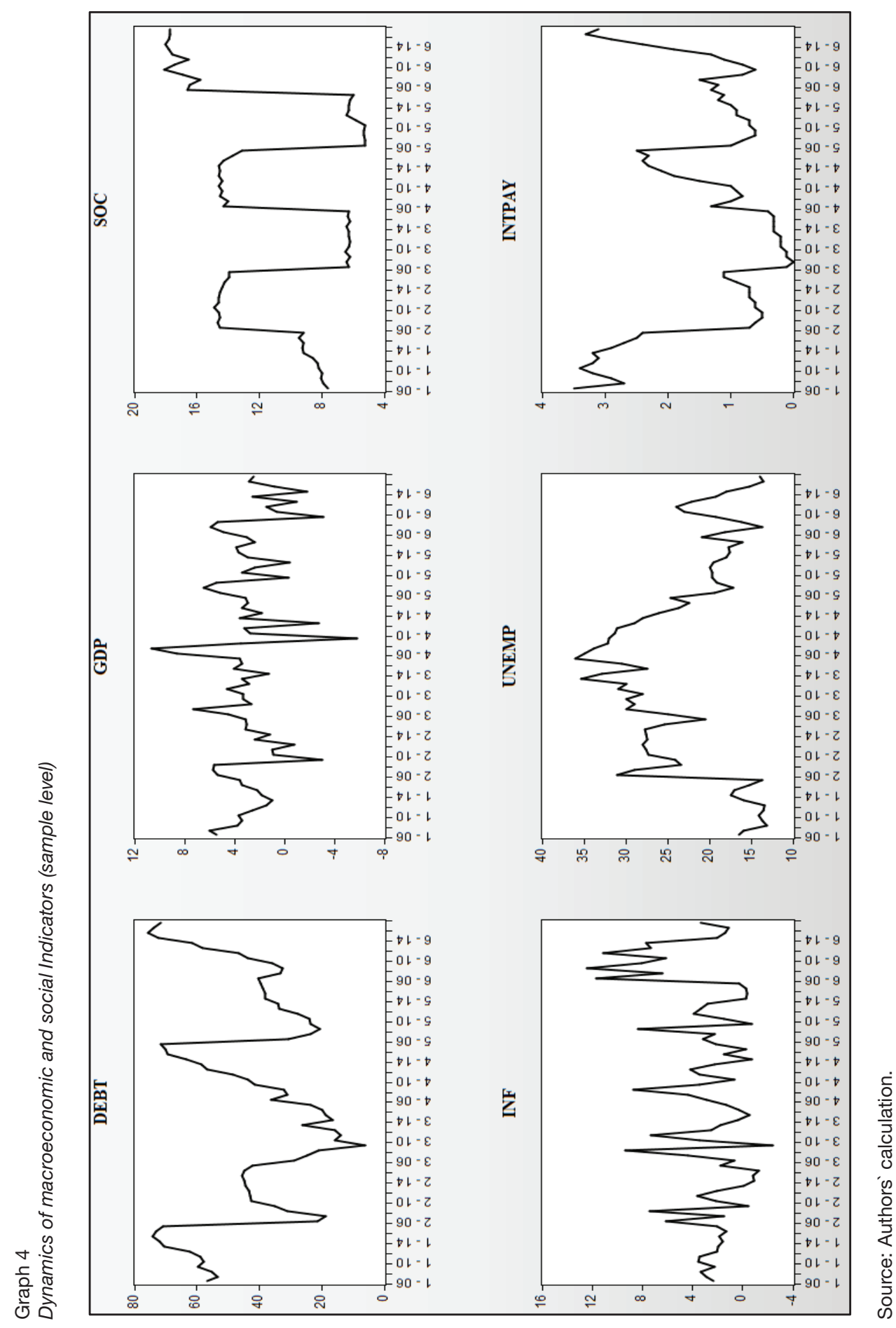


The descriptive statistics across the variables is presented in Appendix (see Table A1 and Table A2). As we can see, there is a huge difference in the variability of the indicators, judging by the standard deviation. Specifically, the overall standard deviation points to some highly volatile variables, such as debt (both level and lagged values), unemployment and social costs. On the other hand, some other variables, such as GDP growth and interest payment, exhibit quite a stable path. It is worth emphasizing that GDP growth is less volatile than the unemployment rate, which implies that, contrary to common sense, these two variables are not highly correlated. However, if we take into account the cross-sectional variations (between) and throughout the timeframe (within). Namely, the cross-sectional variability effect is much more pronounced for debt (both level and lagged values), social costs, unemployment and interest payment, while the time variability effect dominates for the GDP and inflation.

Another important detail is a visible distributional difference across the initial variables, judging by the skewness and kurtosis (see Table A1). Namely, all the variables have non-zero skewness (though social costs are very close to 0 ), meaning that their distribution has either a long left tail (GDP) or a long right tail (all other variables). Similarly, kurtosis shows that some distributions are peaked (leptokurtic) relative to the normal distribution (the GDP and inflation), while other variables have a flat (platykurtic) distribution relative to the normal. As we have seen, in terms of the tails, social costs are closest to normal distribution, but they have a significantly flatter distribution compared to the normal approximation.

\section{Econometric Results and Discussion}

We start our econometric investigation with stationarity testing, followed by the multicollinearity check. To check for the possible unit roots, we have implemented a series of stationarity checks both at level and first difference, and the results are presented in Appendix (see Table A3 and Table A4). We follow the most rigorous approach, meaning that if any of the stationarity tests show that a variable is non-stationary, then we implement difference transformation. That way, our stationarity analysis is robust to different distributional properties that the tests are based upon. Accordingly, all the variables, excluding the GDP growth rate, are non-stationary at level, meaning that they have to be transformed before the empirical estimation.

Compared to the static panel estimation where the variables at level enter the model, the stationarity problem itself is not so important in the dynamic panel setting, since the variables are by default initially transformed (differenced or lagged), and then included in the estimation procedure. The bottom part of Table A4 shows that all initially non-stationary variables at level became stationary at first difference, implying that our data set, excluding the GDP, is difference stationary.

To address the potential problem of multicollinearity, we have calculated the correlation matrix at first difference, as well as the variance inflation factor (VIF), and the results are presented in Appendix (See Table A5 and Table A6). It is in our interest to firstly check the correlation coefficients among the independent variables. Our data set exhibits a low cross-correlation, meaning that there is no multicollinearity in this case. All the coefficients are far below the predefined multicollinearity indication (about $10.50 \mathrm{I}$ ), and we can conclude that there is no multicollinearity problem. In addition, the VIF results strongly back up this finding, since only VIF value greater than 10 merit further investigation, which corresponds to the tolerance lower level of 0.1 for $1 / V I F$. Our VIG results are far from both the upper and lower tolerance levels, 
implying that our data set is free from multicollinearity.

Before we proceed to the final GMM estimation, we have to implement one additional pre-estimation check. Our concern is related to a possible nonlinear relationship between the independent variables and public debt, but the RESET tests strongly rejects this scenario. Namely, the F-test in the second stage regression has a corresponding p-value equal to 0.994 , which means that the second stage regression does not have any explanatory power. In addition, the adjusted R-squared of -0.08711 confirms that the relationship between the independent variables and public debt is linear.

The results of dynamic panel GMM estimation for both first-difference and system GMM models are presented in Table 1, while a full set of the residual diagnostics is presented in Appendix (see Graph A7, Table A8 and Table A9).

Table 6

GMM results (FD GMM vs. System GMM)

\begin{tabular}{|c|c|c|c|c|}
\hline \multicolumn{5}{|c|}{ [A]: First Difference GMM } \\
\hline Variable & Coefficient & Std. Error & t-Statistic & Prob. \\
\hline C & 4.446889 & 3.983793 & 1.116245 & 0.2688 \\
\hline$\triangle \mathrm{DEBT}$ (lagged) & 0.772599 & 0.077341 & 9.989528 & $0.0000^{\star * *}$ \\
\hline GDP & -0.970394 & 0.326872 & -2.968723 & $0.0042^{* \star *}$ \\
\hline soc & 1.173704 & 0.216113 & 5.430972 & $0.0000^{\star * *}$ \\
\hline INF & -0.589125 & 0.286231 & -2.058215 & $0.0435^{\star \star}$ \\
\hline UNEMP & 0.201580 & 0.273871 & 0.736039 & 0.4652 \\
\hline INTPAY & 0.493646 & 0.193085 & 2.556633 & $0.0132^{\star \star}$ \\
\hline Adjusted R-squared & 28.361154 & \multicolumn{2}{|c|}{ Mean dependent var } & 1.599697 \\
\hline S.E. of regression & 2.282485 & \multicolumn{2}{|c|}{ S.D. dependent var } & 4.957919 \\
\hline Instrument rank & 24 & \multicolumn{2}{|c|}{ Akaike info criterion } & 6.746095 \\
\hline J-statistic & 16.314701 & \multicolumn{2}{|c|}{ Probability (J-statistic) } & 0.570601 \\
\hline \multicolumn{5}{|c|}{ [B]: System GMM } \\
\hline Variable & Coefficient & Std. Error & t-Statistic & Prob. \\
\hline C & 1.804084 & 2.539962 & 0.710280 & 0.4802 \\
\hline$\triangle \mathrm{DEBT}$ (lagged) & 0.878097 & 0.060487 & 14.51703 & $0.0000^{\star * *}$ \\
\hline GDP & -1.305711 & 0.530488 & -2.461341 & $0.0167^{* \star}$ \\
\hline SOC & 0.983279 & 0.038554 & 25.50381 & $0.0000^{\star * *}$ \\
\hline INF & -0.558562 & 0.218195 & -2.559929 & $0.0128^{\star *}$ \\
\hline UNEMP & 0.385841 & 0.406969 & 0.948085 & 0.3468 \\
\hline INTPAY & 0.243185 & 0.125565 & 1.936720 & $0.0571^{*}$ \\
\hline Adjusted R-squared & 34.52166 & \multicolumn{2}{|c|}{ Mean dependent var } & 1.599697 \\
\hline S.E. of regression & 2.14471 & \multicolumn{2}{|c|}{ S.D. dependent var } & 4.957919 \\
\hline Instrument rank & 29 & \multicolumn{2}{|c|}{ Akaike info criterion } & 5.850570 \\
\hline J-statistic & 30.587215 & \multicolumn{2}{|c|}{ Probability (J-statistic) } & 0.13327652 \\
\hline
\end{tabular}

Note: ${ }^{\star \star \star}$ Significance at 1\%; ${ }^{\star \star}$ Significance at 5\%; * Significance at 10\%

Source: Authors`calculation. 
The results are quite instructive, both in terms of the direction and magnitude of the effects, and in terms of policy implications. It is necessary to emphasize that the two dynamic models provide very similar results, though there are some differences in the magnitude of the impact. Also, unemployment proved to be statistically insignificant, contrary to the findings of Castells-Quintana \& Royuela (2012). This can be explained by an unstructured labor market where the number of the unemployed does not correspond to social benefits, since many unemployed people lose their social benefits within a year. Also, many officially unemployed people work on the black market, as a consequence of a social climate dominated by rising poverty and inequality, thus contributing to the economic activity and budget revenues indirectly, primarily through daily consumption. Finally, the methodology that measures the unemployment rate in these countries has undergone significant changes during the observed period, and it is still considered unreliable in many cases.

As we can see in Table 1, all other independent variables, excluding the unemployment rate, have statistically significant effects on public debt. Specifically, the one-period lagged debt is highly significant for debt changes, since we have a well-known negative spillover effect between previous debt levels and incremental debt dynamics. It means that the accumulated past debt determines the future debt increase, implying that public debt is a self-generating process. Accordingly, the accumulated debt is one of the biggest "enemies" of the current fiscal balance and future debt dynamics. Also, GDP growth rate is negatively related to public debt changes: a one percent increase in the incremental growth rate leads to a $0.97 \%$ or $1.31 \%$ decrease (depending on the model) in the debt-to-GDP ratio. This finding is congruent with the results of many other studies (for example, Budina and Fies, 2005; Cherif and Hasanov, 2012; Casadio, Paradiso \& Bhaskara, 2012; Matosec, 2015; Swamy, 2015; Bittencourt, 2015).

According to the econometric results, social costs have procyclical debt effects, meaning that a $1 \%$ increase in social expenditures leads to a $1.17 \%$ or $0.98 \%$ increase (depending on the model) in the debt-toGDP ratio. This evidence is in line with the results of Chang, Lee, Geng and Ning (2016), but contradicts the results of Lee (2017). Furthermore, inflation does contribute to debt reduction, and a $1 \%$ increase in inflation leads to a negative incremental change in the debt-to-GDP ratio for $0.59 \%$ or $0.56 \%$, depending on the specification. We find the same conclusion in the comparable studies of Marion (2011) and Hall and Sargent (2010), while Forslund, Lima and Panizza (2011) do not find inflation to be statistically significant. Finally, interest payments for the previous debt have a positive and significant effect on the debtto-GDP change, supporting our previous assumption that debt is a self-fuelling process. Specifically, a $1 \%$ increase in interest payments reduces the incremental debt-toGDP change by $0.49 \%$ or $0.24 \%$ depending on the model.

Comparatively speaking, both models suggest similar conclusions, and both passed the test of over-identifying restrictions. Namely, we fail to reject the null hypothesis of the validity of the restrictions, which suggests that our instrumental variables (lagged dependent variable) are valid. However, the AIC favors the system GMM model, since it has a slightly lower amount of information lost, compared to the first difference GMM. In addition, the number of instruments in both specifications is 4 and 5, respectively, since the number of instruments is collapsed using the second-lag instruments. Accordingly, we have a plausible estimation of the GMM coeffi- 
cients, according to the recommendations by Roodman (2009).

As for the residual diagnostics, Graph A7 in Appendix presents the histogram and supporting normality test of the residuals (Jacque Berra). Accordingly, the residuals approximately follow normal distribution, since we failed to reject the null hypothesis. Additional residual checks (between different lags and within the cross-sections) are presented in Appendix (see Table A8 and Table A9). The results (Table A8) suggest no serial correlation between the residuals, where we have the same conclusion for both test specifications: (a) at each lag (1-3 lags), and (b) between lag 1 and lag 3 . Consequently, the autocorrelation function is located within the independence upper and lower bands. In addition, the residual cross-section dependence test's results (see Table A9) support the null hypothesis, implying no residual cross-sectional dependence. Finally, the A-B autocorrelation test suggests that the first-differenced errors are first-order serially correlated (z-stat $=$ -4.3676 ; $\mathrm{p}$-value $=0.0000$ ), which is natural for the design of the model. On the other hand, there is no significant evidence of a serial correlation in the first-differenced errors at order 2 (z-stat $=-0.34114$; $p$-value $=0.7330$ ), since we failed to reject the null hypothesis. Putting these diagnostic tests together, we conclude that the GMM residuals are independent and identically distributed, which makes our GMM estimation consistent, and the results plausible.

Though the results suggest some important causalities, they cannot be taken as a general recipe due to the pronounced heterogeneity of the countries included in the sample. Moreover, the countries have different current fiscal positions, and not all of them have reached the stated debt-toGDP threshold of $60 \%$. Accordingly, these countries must follow different fiscal strategies, since some of them recorded deficit in
2018 (for example, BIH and Serbia), while others have more favorable current fiscal positions. According to the World Bank (2019), "public debt-to-GDP ratios fell in Serbia, Bosnia and Herzegovina and Albania in 2018. Furthermore, reducing risks to fiscal sustainability requires reining in pension spending, better controlling stateowned enterprise (SOE) debt, increasing discipline in local government financial management, and improving the efficiency of public spending and tax collection." In addition, different fiscal and economic situations across the sample dictate different policy actions and potential remedies. According to Koczan (2015), fiscal strategies are country-specific, mainly oriented toward fiscal consolidation, tax compliance, expenditure reforms, and fiscal adjustments.

\section{CONCLUSIONS AND IMPLICATIONS}

The paper investigates the most important drivers of public debt in the selected Western Balkan countries, with an emphasis on the effects of GDP growth and social expenditures. We employ the dynamic GMM estimator, both first difference and system GMM, in a balanced panel fashion, covering the period 2006-2017. The descriptive analysis shows that public debt, measured as the debt-to-GDP ratio, varies significantly across the sample, while the GDP growth rate in the region is much less volatile. In addition, other indicators also suggest that the country-specific factors dominate the time-trend effect, implying that we are dealing with quite a heterogeneous sample, though countries had a similar transitional history and post-transitional development trajectory.

The econometric results support a significant and negative relationship between GDP growth and public debt, suggesting that a proactive economic policy that fosters economic growth reduces public debt. 
This confirms the well-known fact that only long-term and sound growth driven by the export-oriented economy allows governments to control public debt effectively. In addition, social expenditures are negatively related to public debt, implying that a so-called welfare state is costly in many dimensions. Namely, it requires significant initial amounts and, since they are "sticky" and difficult to be reduced, accumulated social benefits will also result in debt accumulation, with significant final budget spending, social costs and pressures.

More importantly, social protection, as one of the key sources of income for the majority of households, has the highest share in social expenditure, up to $40 \%$ of the total spending. This component has risen especially during the crisis, which was mainly owed to the rise in unemployment. Extensive social assistance programmes give workers disincentives to work as they rely on the state for support and this help was frequently misused. On the other hand, early retirement is another factor that is adding to fiscal pressures. Pensions, together with a social assistance, present a dominant part of household incomes in analysed countries. Even though most of the countries are conducting reforms of their fiscally unsustainable pension systems, pension outlays are still very high. These trends undermine the countries' efforts to use all of their productive capacities in order to achieve a faster economic growth. Due to insufficient domestic accumulation of capital for investment and for financing growing social needs, these countries resort to public debt creation. Having previous considerations in mind, these countries have to implement a large-scale public sector reform, focusing on implementing a market-oriented approach that will favor efficiency.

The study also shows that a high inflation environment reduces public debt, but it is important to bear in mind that higher inflation imposes huge social costs as well. In addressing this issue, our thoughts are in favor of a low and stable inflation environment, since economic theory suggests that price stability is considered an important precondition for a sustainable economic growth in the long-run. Finally, interest payments push the debt-to-GDP up, since accumulated public borrowing creates expost negative budget effects, and it ends up with additional borrowings. A potential remedy is not only to rationalize current budget spending, but also to implement debt repayment whenever the interest rate drops. That way, the total fiscal burden will be lowered, while current budget pressures for further borrowing will be reduced.

Overall, an economic policy that combines pro-growth policy instruments and the structural social reforms would contribute significantly to an efficient public debt management. It is also worth mentioning that an appropriate financial management of the current fiscal deficit and interest payments would create an additional push for sustainable long-term economic progress. In addition, the Western Balkan countries are faced with a typical trade-off. Namely, if they want to maintain and/or improve their welfare setting, they also have to count on an increasing debt-to-GDP ratio that would in the medium term cause future social expenditure to decrease, in order to maintain a sustainable debt in the long run. Thus, future developments require a balanced approach that would protect social benefits, but also allow governments to repay debts timely. Having in mind all the considerations, it is obvious that further economic and fiscal reshuffling is necessary, since all the countries gravitate to the EU membership that implies standardized social and fiscal settings. 


\section{REFERENCES}

Abbas, A. S., Akitoby, Andritzky, J., Berger, H., Komatsuzaki, T., \& Tyson, J. (2014). Reducing public debt when growth is slow. In M. Schindler, H. Berger, B. B. Bakker \& A. Spilimbergo (Eds.), Jobs and Growth: Supporting the European Recovery (pp. 67-93). Washington, D.C.: International Monetary Fund.

Aizenman, J., \& Marion, N. (2011). Using inflation to erode the U.S. Public Debt. Journal of Macroeconomics, 33(4), 524-541. https://doi. org/10.1016/j.jmacro.2011.09.001

Akram, N. (2016). Public debt and pro-poor economic growth evidence from South Asian countries. Economic research - Ekonomska istraživanja, 29(1), 746-757. https://doi.org/10.1080/133167 7X.2016.1197550

Alesina, F. A., \& de Rugy, V. (2014). A review of the scholarship on austerity. In S. Furth (Ed.), Europe's Fiscal Crisis Revealed: An In-Depth Analysis of Spending, Austerity, and Growth (pp. 3-11). Washington, D.C.: The Heritage Foundation.

Alesina, F. A., \& Passalacqua, A. (2016). The political economy of government debt. NBER Working Paper No. w21821. Cambridge, MA: National Bureau of Economic Research.

Anaya, P., \& Pienkowski, A. (2015). What really drives public debt: A holistic approach. IMF Working Paper No.15/137. Washington, D.C.: International Monetary Fund.

Arellano, M. (2003). Modelling optimal instrumental variables for dynamic panel data models. Working Paper No. 0310. Madrid: Centro de Estudios Monetarios y Financieros. Available at https:// www.cemfi.es/ arellano/SIV2015.pdf

Arellano, M., \& Bond, S. (1991). Some tests of specification for panel data: Monte Carlo evidence and an application to employment equations. The Review of Economic Studies, 58(2), 277-297. https://doi.org/10.2307/2297968

Bittencourt, M. (2015). determinants of government and external debt: evidence from the young democracies of South America. Emerging Markets Finance and Trade, 51(3), 463-472.https://doi.or g/10.1080/1540496X.2015.1025667

Blundell, R., \& Bond, S. (1998). Initial conditions and moment restrictions in dynamic panel data models. Journal of Econometrics, 87(1), 115-143. https://doi.org/10.1016/S0304-4076(98)00009-8

Brahmbhatt, M., \& Canuto, O. (2012). Fiscal policy for growth and development. Washington, D.C.: The World Bank. Available at http://documents. worldbank.org/curated/en/ 188351468331462771/ Fiscal-policy-for-growth-and-development

Budina, N., \& Fies, N. (2005). Public debt and its determinants in market access countries. Washington, D.C.: The World Bank.

Cafiso, G., \& Cellini, R. (2012). Evidence on fiscal consolidations and the evolution of public debt in Europe. CESifo Working Paper Series No.4027. Munich: CESifo.

Calvo G., Izquierdo A., \& Talvi, E. (2003). Sudden stops, the real exchange rate, and fiscal sustainability: Argentina's lessons. NBER Working $\mathrm{Pa}$ pers 9828. Cambridge, MA: National Bureau of Economic Research.

Casadio, P., Paradiso, A., \& Rao, B. B. (2012). The dynamics of Italian public debt: Alternative paths for fiscal consolidation. Applied Economics Letters, 19(7), 635-639. https://doi.org/10.1080/135 04851.2011 .591726

Castells-Quintana, D., \& Royuela, V. (2012). Unemployment and long-run economic growth: The role of income inequality and urbanisation. Investigaciones Regionales, (24), 153-173. Available at https://ideas.repec.org/a/ris/invreg/0007. html

Cecchetti, S. G., Mohanty, M. S., \& Zampolli, F. (2011). The real effects of debt. BIS Working Papers No. 352. Basel: Bank for International Settlements.

Čeh Časni, A., Andabaka Badurina, A., \& Basarac Sertić, M. (2014). Public debt and growth: Evidence from Central, Eastern and Southeastern European countries. Zbornik radova Ekonomskog fakulteta u Rijeci, 32(1), 35-51. https://hrcak. srce.hr/123118

Chang, C-P., Lee, C-C., Geng, G-F., \& Ning, S-N. (2016). Does higher government debt link to higher social expenditure? New method, new evidence. Applied Economics, 49(16), 1429-1451. https://doi.org/10.1080/00036846.2015.1044745

Cherif, R., \& Hasanov, F. (2012). Public debt dynamics: The effects of austerity, inflation, and growth shocks. IMF Working Papers No. 12/230. Washington, D.C.: International Monetary Fund.

Cvijanović, V., \& Uvalić, M. (2018). Towards a sustainable economic growth and development in the Western Balkans. Zagreb: Friedrich-Ebert-Stiftung, Regional Office.

Czech, S., \& Tusińska, M. (2016). Economic growth, public debt and social spending. Should welfare state take the blame?. Ekonomia $i$ Prawo - Economics and Law, 15(1), 33-45. https://doi. org/10.12775/EiP.2016.003 
Dalić, M. (2013). Fiscal policy and growth in new member states of the EU: A panel data analysis. Financial theory and practice, 37(4), 335-360. https://doi.org/10.3326/fintp.37.4.1

Daniel, J., Callen, T., Terrones, M. E., Debrun, X., \& Allard, C. (2003). Public debt in emerging markets: Is it too high?. In World economic outlook: A survey by the staff of the International Monetary Fund (pp.113-152). Washington, D.C.: International Monetary Fund.

Easterly, W. (2001). Growth implosions and debt explosions: Do growth slowdowns cause public debt crises?. Contributions in Macroeconomics, 1(1). https://doi.org/10.2202/1534-6005.1013

Egert, B. (2013). The $90 \%$ public debt threshold: The rise and fall of a stylised fact. CESifo Working Papers no. 4242. Munich: CESifo.

Enders, W. (2015). Applied Econometric Time Series (4th ed.). New Jersey: John Wiley \& Sons.

Forslund, K., Lima, L., \& Panizza, U. (2011). The determinants of the composition of public debt in developing and emerging market countries. Review of Development Finance, 1(3-4), 207-222. https://doi.org/10.1016/j.rdf.2011.09.004

Ghosh, A. R., Chamon, M., Crowe, C. W., Kim, J., \& Ostry, J. D. (2009). Coping with the crisis: Policy options for emerging market countries. IMF Staff Position Note No. 8. Washington, D.C.: International Monetary Fund.

Globan, T., \& Matošec, M. (2016). Public debt-toGDP ratio in new EU member states: Cut the numerator or increase the denominator?. Romanian journal of economic forecasting, 19(3), 5772. Available at http://www.ipe.ro/rjef/rjef3_16/ rjef3_2016p57-72.pdf

Guajardo, J., Leigh, D., \& Pescatori, A. (2011). Expansionary austerity - New international evidence. IMF Working Paper No.11/158. Washington, D.C.: International Monetary Fund.

Guscina, A. (2008). Impact of macroeconomic, political, and institutional factors on the structure of government debt in emerging market countries. IMF Working Paper No. 08/205. Washington, D.C.: International Monetary Fund.

Hall, G., \& Sargent, T. (2010). Interest rate risk and other determinants of post-WWII U.S. Government debt/GDP dynamics. NBER Working Paper No. 15702. Cambridge, MA: National Bureau of Economic Research.

Hansen, L. P. (1982). Large sample properties of generalized method of moments estimators. Econometrica, 50(4), 1029-1054. https://doi. org/10.2307/1912775
Im, K. S., Pesaran, M. H. \& Shin, Y. (2003). Testing for unit roots in heterogeneous panels. Journal of Econometrics, 115(1), 53-74. https://doi. org/10.1016/S0304-4076(03)00092-7

International Monetary Fund. (2014). Government Finance Statistics Manual 2014. Washington, D.C.: The International Monetary Fund. Available at https://www.imf.org/external/Pubs/FT/ GFS/Manual/2014/gfsfinal.pdf

International Monetary Fund. (2019). IMF Policy Paper: A Strategy for IMF Engagement on Social Spending. Washington, D.C.: The International Monetary Fund. Available at https:// www.imf.org/en/Publications/Policy-Papers/ Issues/2019/06/10/A-Strategy-for-IMF-Engagement-on-Social-Spending-46975

Koczan, Z. (2015). Fiscal deficit and public debt in the Western Balkans: 15 years of economic transition. IMF Working Paper No. WP/15/172. Available at https://www.imf.org/external/pubs/ ft/wp/2015/wp15172.pdf

Krugman P. (2010, July 7). Self-defeating austerity. The New York Times. Available at https://krugman.blogs.nytimes.com/2010/07/07/self-defeating-austerity/

Kumar, M. S., \& Woo, J. (2010). Public debt and growth. IMF Working Paper No. 10/174. Washington, D.C.: International Monetary Fund.

Lee, I. (2017). Is social expenditure responsible for recent rise in public debt in OECD countries?. Applied Economics Letters, 25(1), 43-46. https:// doi.org/10.1080/13504851.2017.1293778

Levin, A., Lin, C.-F., \& Chu, C.-S. J. (2002). Unit root tests in panel data: Asymptotic and finite-sample properties. Journal of Econometrics, 108(1), 1-24. https://doi.org/10.1016/S03044076(01)00098-7

López, R. E., Thomas, V., \& Wang, Y. (2008). The quality of growth: Fiscal policies for better results. Independent Evaluation Group (IEG) working paper series, No. 2008/6. Washington, D.C.: The World Bank. Available at http://documents.worldbank.org/curated/en/ 254571468339912673/The-quality-of-growthfiscal-policies-for-better-results

Lora,E.,\& Olivera, M. (2007). Public debt and social expenditure: Friends or foes?. Emerging Markets Review, 8(4), 299-310. https://doi.org/10.1016/j. ememar.2006.12.004

Marton, A. (2018). The relationship between fiscal consolidation and sovereign debt - Does fiscal correction decrease or increase debt rate?. Public Finance Quarterly, 63(1), 24-38. 
Mencinger, J., Aristovnik, A., \& Verbič, M. (2014). The impact of growing public debt on economic growth in European Union. The Amfiteatru Economic Journal, 16(35), 403-414. Available at https://mpra.ub.uni-muenchen.de/53243/

Mendoza, E., \& Ostry, J. (2007). International evidence on fiscal solvency: Is fiscal policy responsible. NBER Working Paper No. 12947. Cambridge, MA: National Bureau of Economic Research.

Minea, A., \& Parent, A. (2012). Is high public debt always harmful to economic growth? Reinhart and Rogoff and some complex nonlinearities. CERDI Working Papers, No. 18.

Mota, P.R., Costa Fernandes, A. \& Nicolescu, A.C. (2012). The recent dynamics of public debt in the European Union: A matter of fundamentals or the result of a failed monetary experiment?.FEP Working Paper No. 467. Porto: Universidade do Porto, Faculdade de Economia do Porto.

Panizza, U., \& Presbitero, A. F. (2013). Public debt and economic growth in advanced economies: A survey. Swiss Journal of Economics and Statistics, 149(2), 175-204. https://doi.org/10.1007/ BF03399388

Pečarić, M., Slišković, V., \& Kusanović, T. (2018). Public debt in new EU member states - panel data analysis and managerial implications. Management, 23(1), 81-97. https://doi.org/10.30924/ mjcmi/2018.23.2.81

Pesaran, M. H. (2004). General diagnostic tests for cross section dependence in panels. Cambridge Working Papers in Economics No. 0435. Faculty of Economics, University of Cambridge. Available at https://ideas.repec.org/p/cam/camdae/0435.html

Pirtea, M. G., Nicolescu, A. C., \& Mota, P. R. (2013). An empirical study on public debt's determinants: Evidence from Romania. Transylvanian Review of Administrative Sciences, (38), 144157. Available at https://rtsa.ro/tras/index.php/ tras/article/view/117

Reinhart, C. M., \& Rogoff, K. S. (2010). Debt and growth revisited. MPRA Paper No. 24376. Munich: University Library of Munich.

Roodman, D. (2009). A note on the theme of too many instruments. Oxford Bulletin of Economics and
Statistics, 71(1), 135-158.https://doi.org/10.1111/ j.1468-0084.2008.00542.x

Sever, I., Drezgić, S., \& Blažić, H. (2011), Budget spending and economic growth in Croatia: Dynamics and relationship over the past two decades. Zbornik radova Ekonomskog fakulteta $u$ Rijeci, 29(2), 291-331.https://hrcak.srce.hr/75202

Sinha, P., Arora, V., \& Bansal, V. (2011). Determinants of public debt for middle income and high-income group countries using Panel Data regression. MPRA Paper No. 32079. Munich: University Library of Munich.

Swamy, V. (2015). Government debt and its macroeconomic determinants - An empirical investigation. MPRA Paper No.64106. Munich: University Library of Munich.

Šimović, H. (2018). Impact of public debt sustainability on fiscal policy in Croatia. Acta Oeconomica, 68(2), 231-244. https://doi. org/10.1556/032.2018.68.2.3

Šimović, H., Ćorić, T., \& Deskar-Škrbić, M. (2014). Possibilities and limitations of fiscal policy in Croatia. Ekonomski pregled, 65(6), 541-575. https://hrcak.srce.hr/136626

Taylor, L., Proaño, C., Barbosa de Carvalho, L., \& Barb Barbosa-Filho, N. (2012). Fiscal deficits, economic growth and government debt in the USA. Cambridge Journal of Economics, 36(1), 189-204. https://doi.org/10.1093/cje/ber041

World Bank Group. (2007). Fiscal policy and economic growth: Lessons for Eastern Europe and Central Asia. Washington, D.C.: World Bank. Available at https://openknowledge.worldbank. org/handle/10986/6883.

World Bank Group. (2017). The Western Balkans: Revving up the engines of growth and prosperity (Report No. ACS22690). Washington, D.C.: World Bank Group. Available at https:// openknowledge.worldbank.org/bitstream/handle/10986/28894/ACS22690.pdf

World Bank Group (2019). Reform momentum needed. Western Balkans Regular Economic Report No. 15. Washington, D.C.: World Bank Group. Available at http://documents.worldbank.org/curated/en/219231554130333324/pdf/Reform-Momentum-Needed.pdf 


\title{
Sažetak
}

\section{DINAMIKA JAVNOG DUGA U ZEMLJAMA ZAPADNOG BALKANA: JESU LI SOCIJALNI IZDACI I GOSPODARSKI RAST BITNI?}

\author{
Milena Radonjić, Jovan Đurašković, Milivoje Radović, Julija Cerović Smolović \\ Ekonomski fakultet, Univerzitet Crne Gore \\ Podgorica, Crna Gora
}

Cilj ovog rada je ispitati odrednice javnog duga u zemljama zapadnog Balkana, s naglaskom na učinke gospodarskog rasta i socijalnih izdataka. Studija pokriva razdoblje od 2006. do 2017. godine i primjenjujemo dinamičku panel analizu, korištenjem diferenciranog $i$ sistemskog GMM procjenitelja. Rezultati sugeriraju da inkrementalna promjena rasta značajno smanjuje dug, dok socijalni izdaci podižu omjer duga prema BDP-u. Također, postoji negativan odnos između inflacije i duga, dok otplaćivanje kamata na prethodno zaduživanje dodatno povećava javni dug. Konačno, nezaposlenost u ovom modelu nije statistički značajna. Glavna implikacija studije je da kreatori politika u ovim zemljama trebaju favorizirati politike usmjerene na rast i socijalne reforme orijentirane na djelotvornost, kako bi javni dug bio održiv na duže staze.

Ključne riječi: dug i rast, socijalni izdaci, zapadni Balkan. 


\section{Appendix}

Table A1

Descriptive Statistics

\begin{tabular}{lccccccc}
\hline & DEBT & DEBT[L1*] & GDP & SOC & INF & UNEMP & INTPAY \\
\hline Mean & 42.9832 & 42.05136 & 2.8264 & 11.2560 & 2.9747 & 22.9644 & 1.3694 \\
\hline Median & 41.8600 & 40.87000 & 3.0869 & 13.4000 & 2.2000 & 22.6735 & 1.0000 \\
\hline Maximum & 75.9000 & 75.90000 & 10.6579 & 18.0900 & 12.4100 & 36.0250 & 3.5000 \\
\hline Minimum & 6.1300 & 6.130000 & -5.7951 & 5.2000 & -2.4200 & 13.0600 & 0.0000 \\
\hline Std. Dev. & 18.5836 & 18.25489 & 2.6354 & 4.4886 & 3.1926 & 6.6450 & 1.0262 \\
\hline Skewness & 0.1909 & 0.219534 & -0.4098 & 0.0095 & 1.0655 & 0.1624 & 0.6739 \\
\hline Kurtosis & 1.9695 & 2.049926 & 4.7507 & 1.3812 & 3.7826 & 1.7737 & 2.0945 \\
\hline
\end{tabular}

Observations

72

66

72

72

72

72

72

* one-period lagged debt

Source: Authors`calculation.

Table A2

Variance and Mean Decomposition

\begin{tabular}{|c|c|c|c|c|c|c|}
\hline Variable & Dimension & Mean & Std. Dev & Min & Max & Obs. \\
\hline & overall & 42.98319 & 18.58355 & 6.13 & 75.9 & $\mathrm{~N}=72$ \\
\hline \multirow[t]{3}{*}{ DEBT } & between & & 16.46038 & 19.28583 & 63.7075 & $n=6$ \\
\hline & within & & 10.78802 & 21.55153 & 65.05153 & $\mathrm{~T}=12$ \\
\hline & overall & 42.05136 & 18.25489 & 6.13 & 75.9 & $N=66$ \\
\hline \multirow[t]{3}{*}{ DEBT[L1*] } & between & & 16.14567 & 18.90636 & 63.06273 & $\mathrm{n}=6$ \\
\hline & within & & 10.61429 & 22.23318 & 65.73318 & $\mathrm{~T}=11$ \\
\hline & overall & 2.826403 & 2.635404 & -5.7951 & 10.6579 & $\mathrm{~N}=72$ \\
\hline \multirow[t]{3}{*}{ GDP } & between & & 0.702897 & 1.734164 & 3.687228 & $\mathrm{n}=6$ \\
\hline & within & & 2.554963 & -5.87994 & 10.57306 & $\mathrm{~T}=12$ \\
\hline & overall & 11.25597 & 4.488613 & 5.2 & 18.09 & $\mathrm{~N}=72$ \\
\hline \multirow[t]{3}{*}{ soc } & between & & 4.665887 & 6.31 & 17.3225 & $\mathrm{n}=6$ \\
\hline & within & & 1.32289 & 9.733472 & 21.20597 & $\mathrm{~T}=12$ \\
\hline & overall & 2.974722 & 3.192633 & -2.42 & 12.41 & $\mathrm{~N}=72$ \\
\hline \multirow[t]{3}{*}{ INF } & between & & 1.794626 & 1.7725 & 6.575 & $\mathrm{n}=6$ \\
\hline & within & & 2.73335 & -2.48028 & 9.938889 & $\mathrm{~T}=12$ \\
\hline & overall & 22.96443 & 6.645013 & 13.06 & 36.025 & $\mathrm{~N}=72$ \\
\hline \multirow[t]{3}{*}{ UNEMP } & between & & 6.528806 & 14.95358 & 30.42708 & $n=6$ \\
\hline & within & & 2.85216 & 16.24843 & 28.95418 & $\mathrm{~T}=12$ \\
\hline & overall & 1.369444 & 1.026225 & 0 & 3.5 & $\mathrm{~N}=72$ \\
\hline \multirow[t]{2}{*}{ INTPAY } & between & & 0.978628 & 0.208333 & 2.975 & $n=6$ \\
\hline & within & & 0.493764 & 0.227778 & 2.927778 & $\mathrm{~T}=12$ \\
\hline
\end{tabular}

* one-period lagged debt

Source: Authors' calculation. 


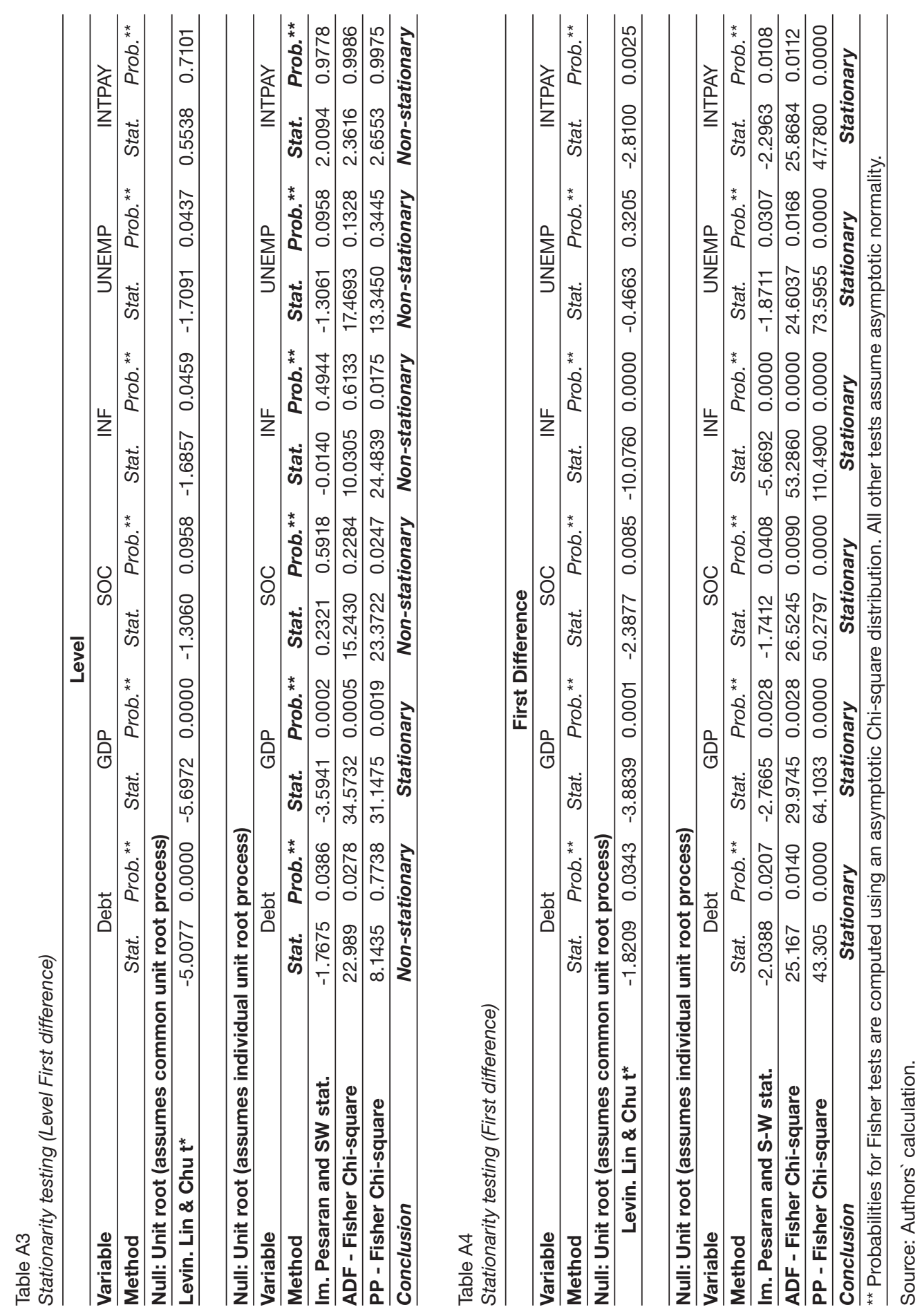


Table A5

Correlation matrix (First difference; $D=$ differenced)

\begin{tabular}{|c|c|c|c|c|c|c|}
\hline & $\mathrm{D}(\mathrm{DEBT})$ & D(DEBT[L1]*) & $D(G D P)$ & $\mathrm{D}(\mathrm{SOC})$ & D(INF) & D(UNEMP)D(INTPAY) \\
\hline DEBT & 1 & & & & & \\
\hline D(LDEBT)* & 0.3429 & 1 & & & & \\
\hline$D(G D P)$ & 0.1327 & 0.2207 & 1 & & & \\
\hline $\mathrm{D}(\mathrm{SOC})$ & -0.1002 & -0.1373 & -0.3016 & 1 & & \\
\hline D(INF) & -0.0128 & -0.2118 & 0.2220 & -0.1475 & 1 & \\
\hline D(UNEMP) & -0.1806 & 0.0858 & -0.0107 & 0.1623 & -0.0311 & 1 \\
\hline D(INTPAY) & 0.2183 & 0.3809 & 0.1517 & -0.2744 & -0.1396 & -0.1450 \\
\hline
\end{tabular}

* one-period lagged debt

Source: Authors calculation.

Table A6

Variance Inflation Factor (VIF)

\begin{tabular}{lll}
\hline Variable & VIF & $\mathbf{1 / \text { VIF }}$ \\
\hline UNEMP & 1.14 & 0.875590 \\
\hline SOC & 1.10 & 0.909737 \\
\hline GDP & 1.09 & 0.917858 \\
\hline INF & 1.09 & 0.917858 \\
\hline INTPAY & 1.06 & 0.943738 \\
\hline L(DEBT) & 1.06 & 0.943738 \\
\hline Mean VIF & 1.09 & --------- \\
\hline
\end{tabular}

Source: Authors' calculation.

\section{Graph A7}

Jacque-Berra Residual Normality Test

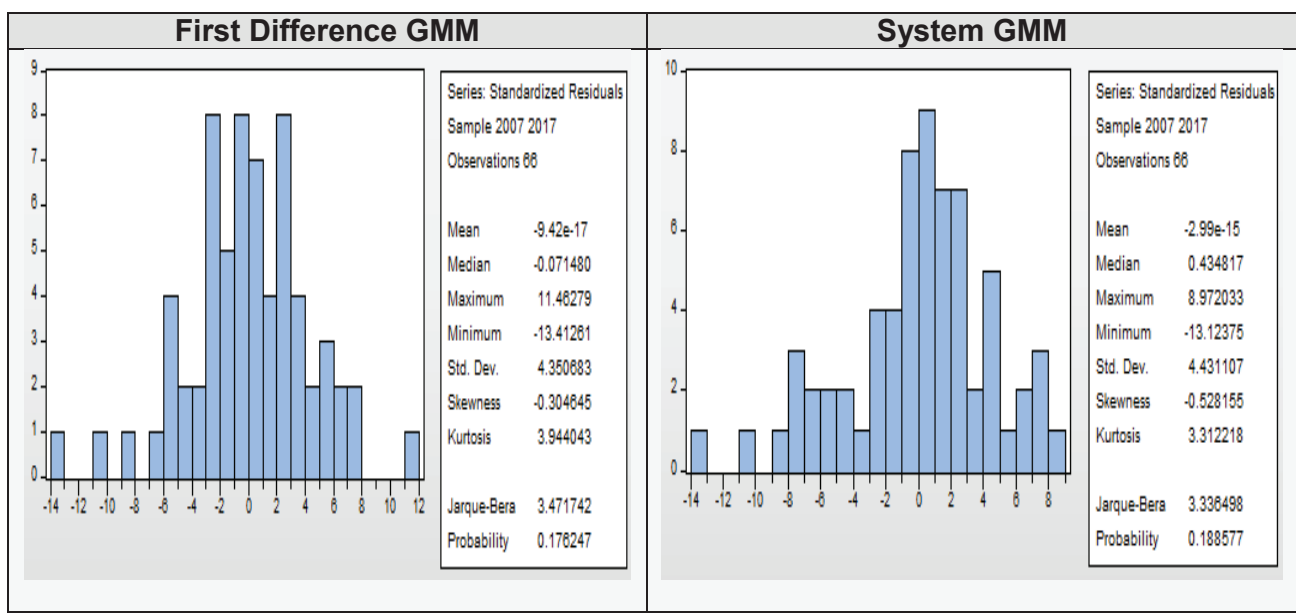

Source: Authors`calculation. 
Table A8

GMM Residual Serial Correlation LM Tests

[A]: First Difference GMM HO: No serial correlation at lag $h$

\section{[B]: System GMM}

HO: No serial correlation at lag $h$

\begin{tabular}{llllllllll}
\hline \multirow{\Xi}{\Xi}{} & LRE* stat & Prob. & Rao F-stat & Prob. & $\underset{\Xi}{\Xi}$ & LRE* stat & Prob. & Rao F-stat & Prob. \\
\hline $\mathbf{1}$ & 31.61038 & 0.1696 & 1.27038 & 0.1697 & 1 & 20.86401 & 0.1838 & 1.31123 & 0.1838 \\
\hline $\mathbf{2}$ & 27.49355 & 0.3317 & 1.10271 & 0.3318 & 2 & 20.42534 & 0.2017 & 1.28321 & 0.2017 \\
\hline $\mathbf{3}$ & 12.17391 & 0.9851 & 0.48371 & 0.9851 & 3 & 8.687644 & 0.9257 & 0.54062 & 0.9257 \\
\hline
\end{tabular}

HO: No serial correlation at lags 1 to $h$ HO: No serial correlation at lags 1 to $h$

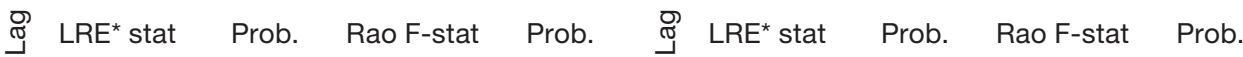

\begin{tabular}{llllllllll}
\hline $\mathbf{1}$ & 23.0672 & 0.1119 & 1.45033 & 0.112 & $\mathbf{1}$ & 18.59192 & 0.2904 & 1.16683 & 0.2905 \\
\hline $\mathbf{2}$ & 18.61755 & 0.289 & 1.16712 & 0.289 & $\mathbf{2}$ & 20.81829 & 0.1856 & 1.30923 & 0.1857 \\
\hline $\mathbf{3}$ & 20.57106 & 0.1956 & 1.29125 & 0.1956 & $\mathbf{3}$ & 7.318958 & 0.9666 & 0.45462 & 0.9666 \\
\hline
\end{tabular}

*Edgeworth expansion corrected likelihood ratio statistic.

Source: Authors` calculation.

Table A9

Residual Cross-Section Dependence Test

\begin{tabular}{lcclcc}
\hline Test & Statistic & Prob. & \multicolumn{1}{c}{ Test } & Statistic & Prob. \\
\hline Null hypothesis: No cross-section dependence & in residuals & & \\
\hline Breusch-Pagan LM & 14.26053 & 0.5059 & Breusch-Pagan LM & 13.76523 & 0.5434 \\
\hline Pesaran scaled LM & -0.13501 & 0.8926 & Pesaran scaled LM & -0.22544 & 0.8216 \\
\hline Pesaran CD & 0.237921 & 0.8119 & Pesaran CD & 0.70906 & 0.4783 \\
\hline
\end{tabular}

Source: Authors' calculation. 